Cover. 1995 aerial photograph of the Lake Linganore study area, Frederick County, Maryland, from the U.S. Department of Agriculture (USDA) National Agriculture Imagery Program (NAIP). 


\section{Water Volume and Sediment Accumulation in Lake Linganore, Frederick County, Maryland, 2009}

By Andrew J. Sekellick and William S.L. Banks

Prepared in cooperation with

Frederick County, Maryland and the

City of Frederick, Maryland

Scientific Investigations Report 2010-5174 


\section{U.S. Department of the Interior \\ KEN SALAZAR, Secretary \\ U.S. Geological Survey \\ Marcia K. McNutt, Director}

U.S. Geological Survey, Reston, Virginia: 2010

For more information on the USGS - the Federal source for science about the Earth, its natural and living resources, natural hazards, and the environment, visit http://www.usgs.gov or call 1-888-ASK-USGS

For an overview of USGS information products, including maps, imagery, and publications, visit http://www.usgs.gov/pubprod

To order this and other USGS information products, visit http://store.usgs.gov

Any use of trade, product, or firm names is for descriptive purposes only and does not imply endorsement by the U.S. Government.

Although this report is in the public domain, permission must be secured from the individual copyright owners to reproduce any copyrighted materials contained within this report.

Suggested citation:

Sekellick, A.J., and Banks, W.S.L., 2010, Water volume and sediment accumulation in Lake Linganore, Frederick County, Maryland, 2009: U.S. Geological Survey Scientific Investigations Report 2010-5174, 14 p. 


\section{Contents}

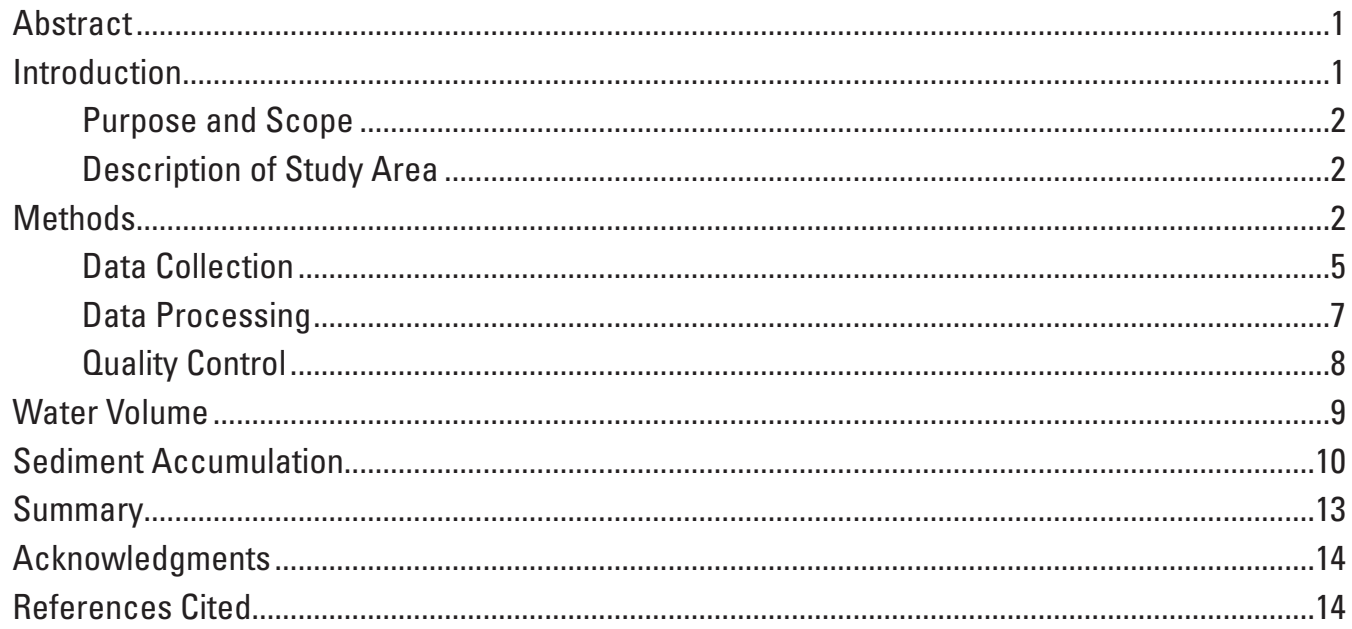

\section{Figures}

1-2. Maps showing-

1a. Location of Linganore Creek watershed, Frederick County, Maryland .....................3

1b. Location of Lake Linganore study area, Frederick County, Maryland ........................4

2. Planned survey lines with 100 -foot transect spacing and qualitycontrol lines with 500-foot transect spacing, Lake Linganore, Maryland, 2009

3-4. Photographs showing-

3. Placement of echosounding equipment and global positioning system mounted on the bow of the work boat .6

4. Work boat and data-collection and processing equipment........................................6

5. Map showing collected data points, target data points, and qualityassurance data points, Lake Linganore, Maryland, 2009

6. Graph showing raw data and non-bottom reflectors, Lake Linganore,

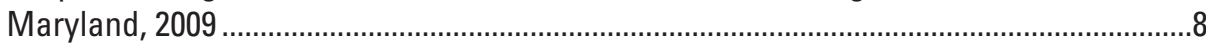

7. Map showing bathymetric contours of Lake Linganore, Maryland, 2009.......................10

8. Graph showing elevation-capacity curve for Lake Linganore, Maryland, 2009

9-10. Maps showing-

9. Study sections of Lake Linganore, Maryland, 2009.

10. Sediment accretion and scour in Lake Linganore, Maryland, 2009.

11. Diagram showing generalized cross section of Lake Linganore from section 1, Lake Linganore, Maryland, 2009 


\section{Tables}

1. Area/capacity from Triangulated Irregular Network model of bathymetric data collected from Lake Linganore, Frederick County, Maryland, 2009

2. Water-storage capacity, water volume, and sediment accumulation in Lake Linganore, Frederick County, Maryland, 2009

\section{Conversion Factors and Datums}

\begin{tabular}{|c|c|c|}
\hline Multiply & By & To obtain \\
\hline \multicolumn{3}{|c|}{ Length } \\
\hline foot (ft) & 0.3048 & meter $(\mathrm{m})$ \\
\hline mile (mi) & 1.609 & kilometer (km) \\
\hline \multicolumn{3}{|c|}{ Area } \\
\hline acre & 4,047 & square meter $\left(\mathrm{m}^{2}\right)$ \\
\hline acre & 0.004047 & square kilometer $\left(\mathrm{km}^{2}\right)$ \\
\hline square mile $\left(\mathrm{mi}^{2}\right)$ & 2.590 & square kilometer $\left(\mathrm{km}^{2}\right)$ \\
\hline \multicolumn{3}{|c|}{ Volume } \\
\hline gallon (gal) & 3.785 & liter (L) \\
\hline gallon (gal) & 0.003785 & cubic meter $\left(\mathrm{m}^{3}\right)$ \\
\hline million gallons (Mgal) & 3,785 & cubic meter $\left(\mathrm{m}^{3}\right)$ \\
\hline acre-foot (acre-ft) & 1,233 & cubic meter $\left(\mathrm{m}^{3}\right)$ \\
\hline cubic yard $\left(\mathrm{yd}^{3}\right)$ & 0.7646 & cubic meter $\left(\mathrm{m}^{3}\right)$ \\
\hline
\end{tabular}

Temperature in degrees Fahrenheit $\left({ }^{\circ} \mathrm{F}\right)$ may be converted to degrees Celsius $\left({ }^{\circ} \mathrm{C}\right)$ as follows:

$$
{ }^{\circ} \mathrm{C}=\left({ }^{\circ} \mathrm{F}-32\right) / 1.8
$$

Vertical coordinate information is referenced to the North American Vertical Datum of 1988 (NAVD 88).

Horizontal coordinate information is referenced to the North American Datum of 1983 (NAD 83).

Elevation, as used in this report, refers to distance above the vertical datum. 




\title{
Water Volume and Sediment Accumulation in Lake Linganore, Frederick County, Maryland, 2009
}

\author{
By Andrew J. Sekellick and William S.L. Banks
}

\section{Abstract}

To assist in understanding sediment and phosphorus loadings and the management of water resources, a bathymetric survey was conducted at Lake Linganore in Frederick County, Maryland in June 2009 by the U.S. Geological Survey, in cooperation with the City of Frederick and Frederick County, Maryland. Position data and water-depth data were collected using a survey grade echo sounder and a differentially corrected global positioning system. Data were compiled and edited using geographic information system software. A threedimensional triangulated irregular network model of the lake bottom was created to calculate the volume of stored water in the reservoir. Large-scale topographic maps of the valley prior to inundation in 1972 were provided by the City of Frederick and digitized. The two surfaces were compared and a sediment volume was calculated. Cartographic representations of both water depth and sediment accumulation were produced along with an area/capacity table. An accuracy assessment was completed on the resulting bathymetric model. Vertical accuracy at the 95-percent confidence level for the collected data, the bathymetric surface model, and the bathymetric contour map was calculated to be 0.95 feet, 1.53 feet, and 3.63 feet, respectively.

The water storage volume of Lake Linganore was calculated to be 1,860 acre-feet at full pool elevation. Water volume in the reservoir has decreased by 350 acre-feet (about 16 percent) in the 37 years since the dam was constructed. The total calculated volume of sediment deposited in the lake since 1972 is 313 acre-feet. This represents an average rate of sediment accumulation of 8.5 acre-feet per year since Linganore Creek was impounded. A sectional analysis of sediment distribution indicates that the most upstream third of Lake Linganore contains the largest volume of sediment whereas the section closest to the dam contains the largest amount of water. In comparison to other Maryland Piedmont reservoirs, Lake Linganore was found to have one of the lowest sedimentation rates at 0.26 cubic yards per year per acre of drainage area. Sedimentation rates in other comparable Maryland reservoirs were Prettyboy Reservoir (filling at a rate of 2.26 cubic yards per year per acre), Loch Raven Reservoir (filling at a rate of 0.88 cubic yards per year per acre) and Piney Run Reservoir (filling at a negligible rate).

\section{Introduction}

The U.S. Environmental Protection Agency has identified the Lower Monocacy River, a tributary to the Chesapeake Bay, as impaired by sediment and nutrients, and has imposed a sediment and phosphorus Total Maximum Daily Load (TMDL) (Maryland Department of the Environment, 2002). Linganore Creek is a tributary of the Lower Monocacy River. Lake Linganore, an impoundment on Linganore Creek, provides water to the City of Frederick and Frederick County, Maryland. To meet the TMDL regulatory requirement, and assist the City of Frederick and Frederick County, Maryland in mitigating sediment and phosphorus loadings and manage their water resources, it is necessary to understand the amount of water impounded in Lake Linganore and to accurately quantify the volume of sediment behind the dam to allow the City and County to meet their water-use needs. To address these issues, the City of Frederick and Frederick County asked the U.S. Geological Survey (USGS) to investigate water volume and sediment accumulation in the lake.

As a result of sedimentation problems in the contributing waters, the capacity of Lake Linganore has decreased (Frederick County, Maryland, 2006). In order to effectively and efficiently manage water resources, the City of Frederick and Frederick County have twice estimated the water capacity of Lake Linganore. A 1980 report provided an initial estimate of water volume for the reservoir of 2,710 acre- $\mathrm{ft}$ (acre-feet) as constructed (Zeigler, 1980). The parameters of this first survey are not well documented and the extent of the reservoir during the survey is not known. In 2002, the City of Frederick and Fredrick County hired a contractor to produce a siltation and capacity report that determined lake volume was 2,240 acre-ft in 1999. This same report estimated a pre-reservoir water capacity of 2,560 acre-ft based on 2-ft (foot) contour intervals surveyed prior to dam construction. This corresponds to a volume loss of 320 acre-ft (12.5 percent) (Whitman, Requardt \& Associates, 2002). The methods and extents of the reservoir reported in Zeigler (1980) and Whitman, Requardt \& Associates (2002) are not the same as those used in this report. Direct comparisons between this study and historical studies should not be made. All calculations of potential water volume loss and sediment accumulation in the current study are based on the methods described herein and compare 
current measured volume to theoretical volumes as calculated from 1972 topography between the dam and Boyers Mill Road bridge.

\section{Purpose and Scope}

This report describes the water-storage capacity and sediment accumulation in Lake Linganore in Frederick County, Maryland from 1972 through 2009. This report also describes methods used to collect and process the bathymetric data necessary to determine the elevation of the lake bottom and compute the water volume of the reservoir. In addition, the report describes an accuracy assessment of the collected environmental dataset and the methods described above.

\section{Description of Study Area}

Lake Linganore is located on Linganore Creek in central Frederick County, Maryland, 35 miles west of Baltimore, Maryland (fig. 1a). Linganore Creek drains part of the Piedmont Physiographic Province. The area is characterized by rolling hills and moderately to deeply incised, well-drained valleys with altitudes ranging from sea level to more than 900 $\mathrm{ft}$ above sea level (DiLisio, 1983). The lake was created in 1972 by construction of an earthen dam on Linganore Creek. The impoundment, as designed, extends from the dam to a point $2 \mathrm{mi}$ (miles) upstream. For the purposes of this study, the extent of the reservoir is limited to the part of the lake downstream of Boyers Mill Road. Therefore, water volume calculations and areas of sediment accretion and scour are limited to this area (fig. 1b).

The lake was originally constructed for recreation purposes for the private community of Lake Linganore at Eaglehead. The reservoir currently serves as one part of the City of Frederick's water supply and provides part of the water supply for Frederick County. In 2009, the City of Frederick was permitted to withdraw $6.0 \mathrm{Mgal} / \mathrm{d}$ (million gallons per day), while keeping a minimum of $4.5 \mathrm{Mgal} / \mathrm{d}$ passing over the dam for ecological health downstream in Linganore Creek (Frederick County, Maryland, 2006). The County is permitted to withdraw an additional $1.2 \mathrm{Mgal} / \mathrm{d}$ as long as the lake's pool elevation is at least $308 \mathrm{ft}$, the elevation of the spillway (Michael Marschner, Director of Public Utilities and Solid Waste, Frederick County, Maryland, written commun., February 24, 2010).

Precipitation in the basin averages 40.64 inches per year. Temperatures range from a July mean of 77.9 degrees Fahrenheit to a December mean of 33.3 degrees Fahrenheit (National Oceanic and Atmospheric Administration, 2006). Land use in the $81.1-\mathrm{mi}^{2}$ (square mile) watershed is 16 percent developed, 56 percent agriculture, and 28 percent forested and other land uses (Maryland Department of the Environment, 2002). Frederick County is within commuting distance to the Washington, D.C. and Baltimore, Maryland metropoli$\tan$ areas and has experienced population growth in the last decade. During the 1990s, the population of Frederick County increased by 30 percent ( 45,000 people) (U.S. Census Bureau, 2009). Land-use conversion and the expansion of impervious surfaces can cause increases in stormwater runoff, streamflow, erosion, and sediment and phosphorus loadings, such as those that have had a significant impact on the water quality of the Chesapeake Bay and its tributaries (Gellis and others, 2009).

\section{Methods}

The commercial hydrographic survey software package HYPACK was used for planning, data acquisition, and data management before, during, and after the survey (HYPACK, 2008). Survey lines (pre-planned lines designed to guide datacollection operations) were created at 100 -ft intervals along the long (east-west) axis of the lake. The transect spacing was computed to optimize data coverage and accuracy and resulted in a data-collection line spacing of approximately 1 percent of the longitudinal distance of the lake for optimum coverage detail (Wilson and Richards, 2006) (fig. 2). Using this transect spacing, $12.7 \mathrm{mi}$ of data-collection lines were planned for the survey. In order to maximize accuracy, survey lines were oriented perpendicular to the shoreline. As the geometry of the lake changed, the orientation of survey lines was rotated to best maintain an optimum perpendicular relation to the shoreline.

In addition to the survey lines described, a separate set of quality-assurance transect lines were planned to provide independent measurements of precision and bias. These lines, oriented at approximately a 45-degree angle to the survey lines, provided an independent measurement of depth on the basis of differing field conditions at points where they intersected with the environmental survey lines. Sixteen of these quality-assurance lines were spaced at 500-ft intervals between Boyers Mill Road and the dam, and provided approximately 90 coincidental points (fig. 2). Once spacing and orientation of the survey lines were planned, both the environmental transects (100-ft spacing) and the qualityassurance transects (500-ft spacing) were imported into the HYPACK software to guide the field crew during data collection. The horizontal projection of the survey was Universal Transverse Mercator Zone 18 North, North American Datum of 1983 (UTM, NAD83) and the vertical control datum was North American Vertical Datum of 1988 (NAVD 88). These projections were used for both the Geographic Information System (GIS) and HYPACK platforms. 

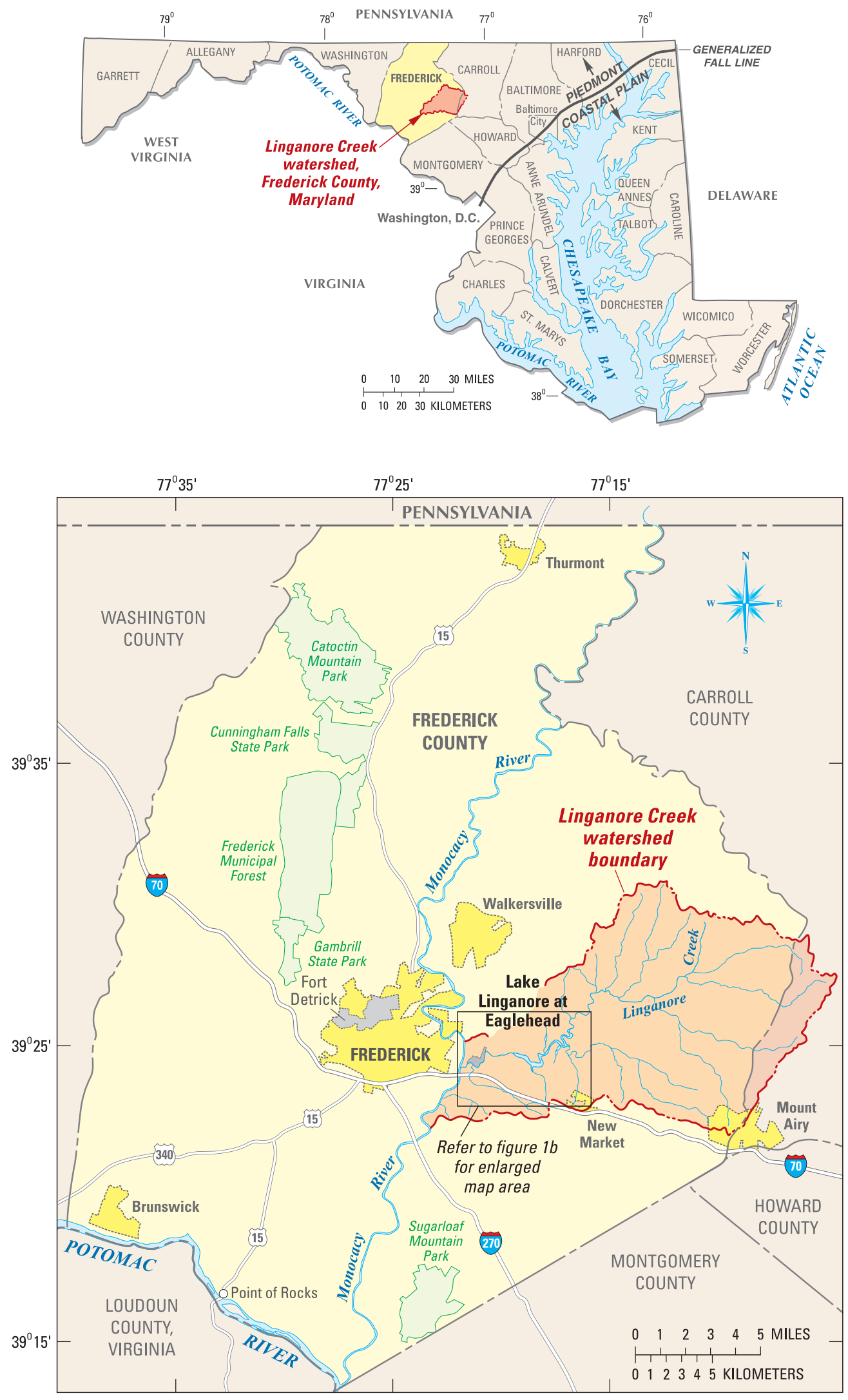

Figure 1a. Location of Linganore Creek watershed, Frederick County, Maryland. 


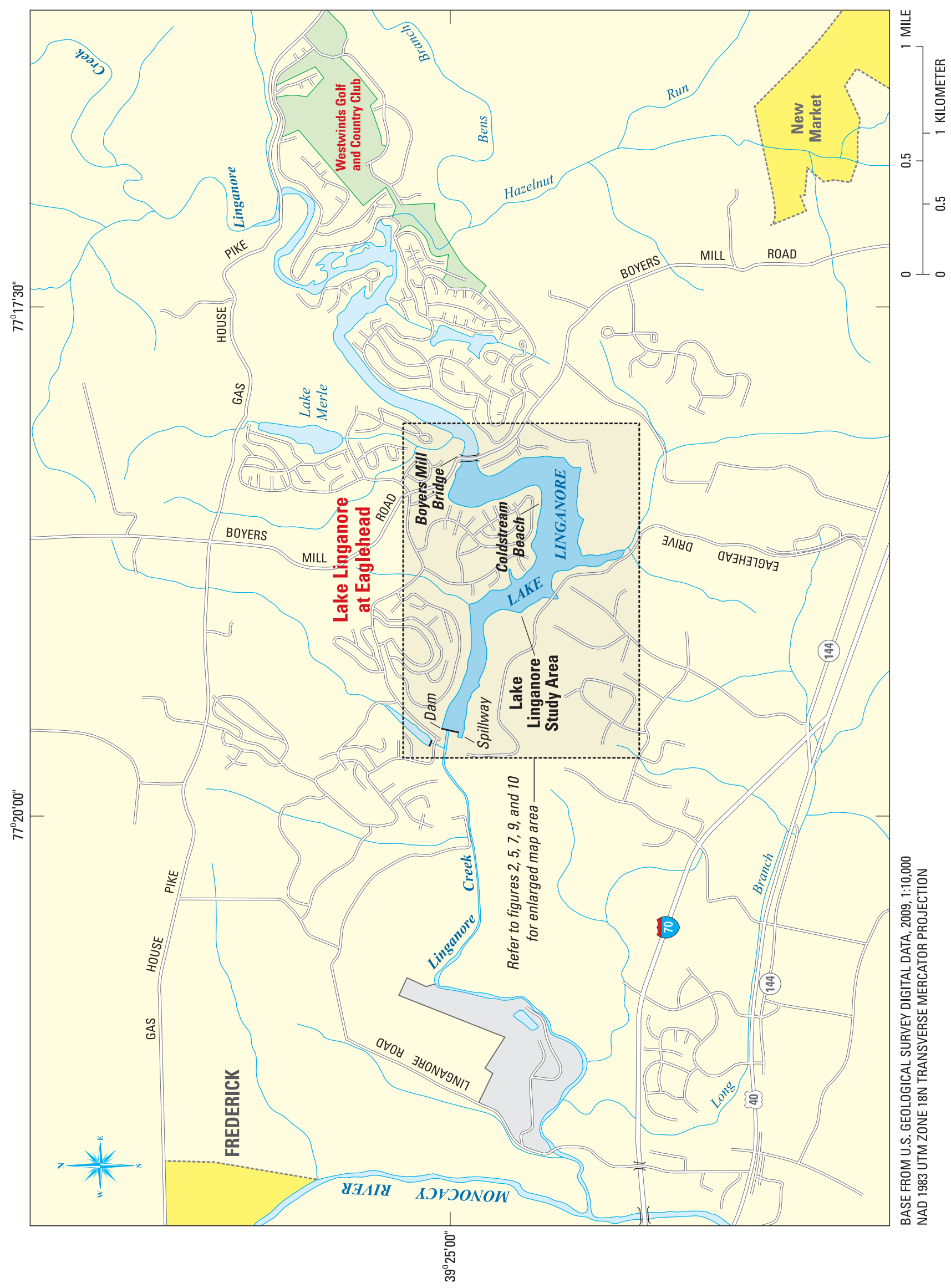

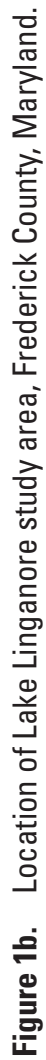




\section{Data Collection}

Bathymetric data were collected using an Ocean Data Equipment Corporation Bathy-500MF Survey Echo Sounder with a $200 \mathrm{KHz}$ (kilohertz) transducer with a beam width of 3 degrees. Echo sounding transducers emit ultrasonic energy that is reflected and refracted off the lake bottom. A portion of this signal is returned to a receiver aboard the transmitting vessel and recorded as a two-way traveltime. This process allows depth calculations based on a known velocity of sound in water. Because water temperature affects this velocity, water temperature was measured and recorded to assist in calibrating the transducer. Depth calibration was performed twice daily (each morning and at mid day) by placing a metal plate at a known depth below the transducer at different locations in the lake. The depth on the plate was noted and a temperature-adjusted measurement of the speed of sound was used to adjust the measured depth to match the known depth of the metal plate. Positional data was collected using a Trimble AgGPS differentially corrected global positioning system (GPS) receiver that provided latitude and longitude with a horizontal accuracy of at least $3.28 \mathrm{ft}$ as stated by the manufacturer (Trimble Navigation Limited, 1999). Survey transects were redone if differential signal was lost during data collection. The GPS receiver was coincidental (within 1 $\mathrm{ft}$ ) with the location of the bathymetric transducer-both were located on the bow of the boat (fig. 3).

Data were collected on June 11, 15, 17, and 23, 2009. All data-collection platforms were mounted aboard an aluminumhulled, dual pontoon work boat with an outboard motor (fig. 4). Work crews consisted of a boat operator and two members of the USGS Maryland-Delaware-District of Columbia Water Science Center. The water elevation at the spillway was recorded each day prior to data collection and at least one other time during each day. Calibration of the echo sounder was performed as previously described prior to data collection and at midday.

Input data from all sensors and navigation equipment were processed by HYPACK using an onboard laptop computer. Depth and GPS coordinates were displayed in real time

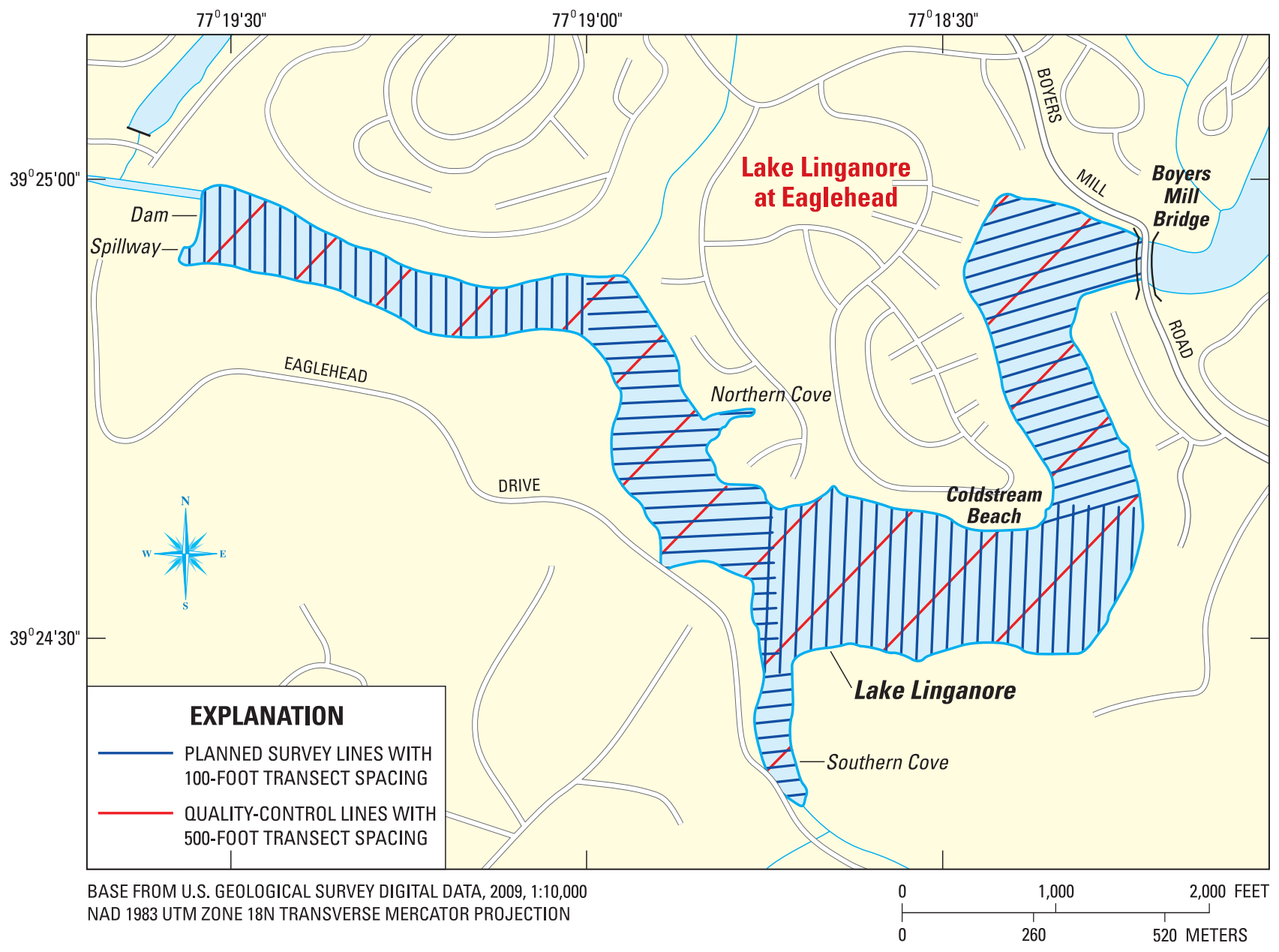

Figure 2. Planned survey lines with 100 -foot transect spacing and quality-control lines with 500 -foot transect spacing, Lake Linganore, Maryland, 2009. 


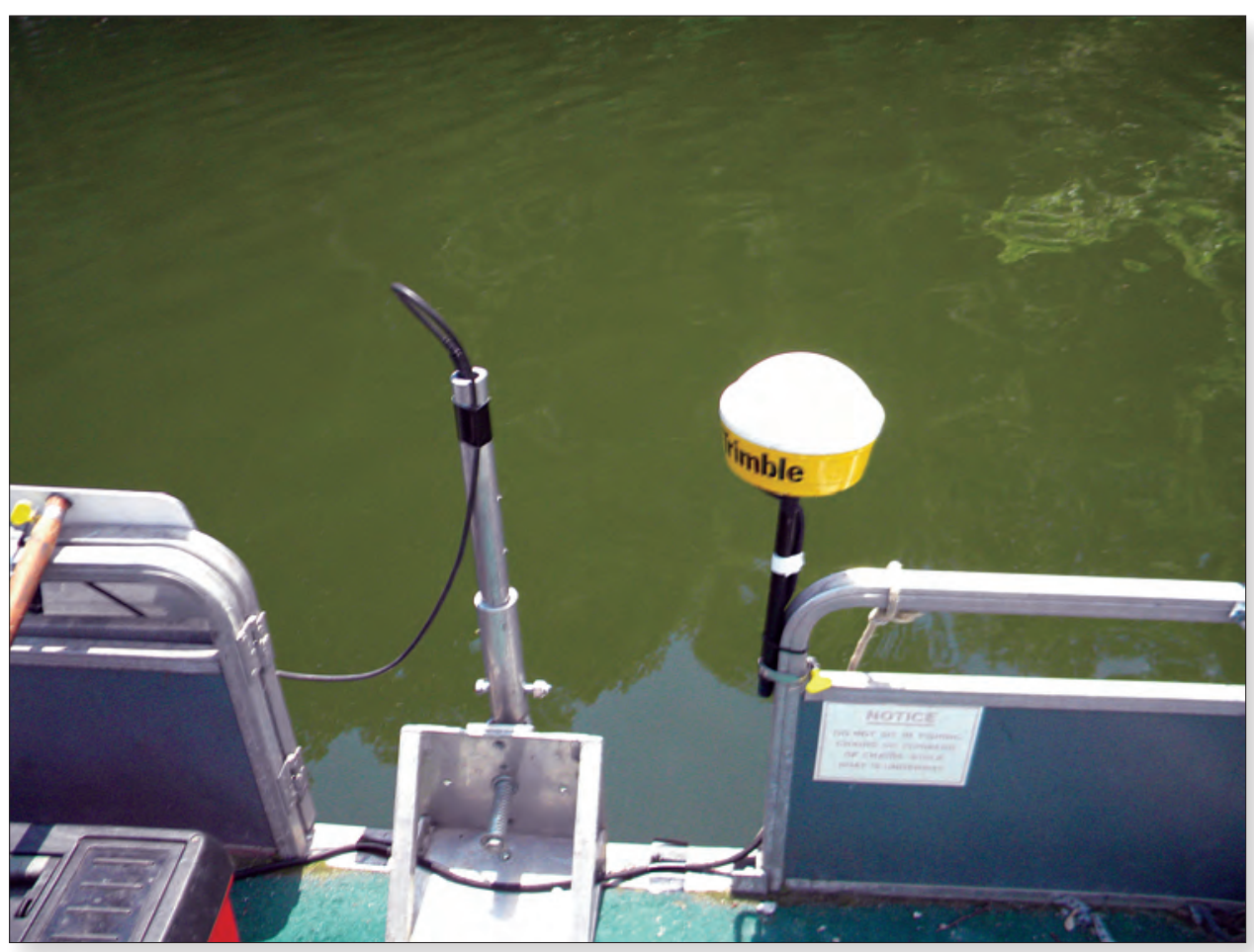

Figure 3. Placement of echo-sounding equipment and global positioning system mounted on the bow of the work boat. [Photograph by William Banks, U.S. Geological Survey, 2009.]

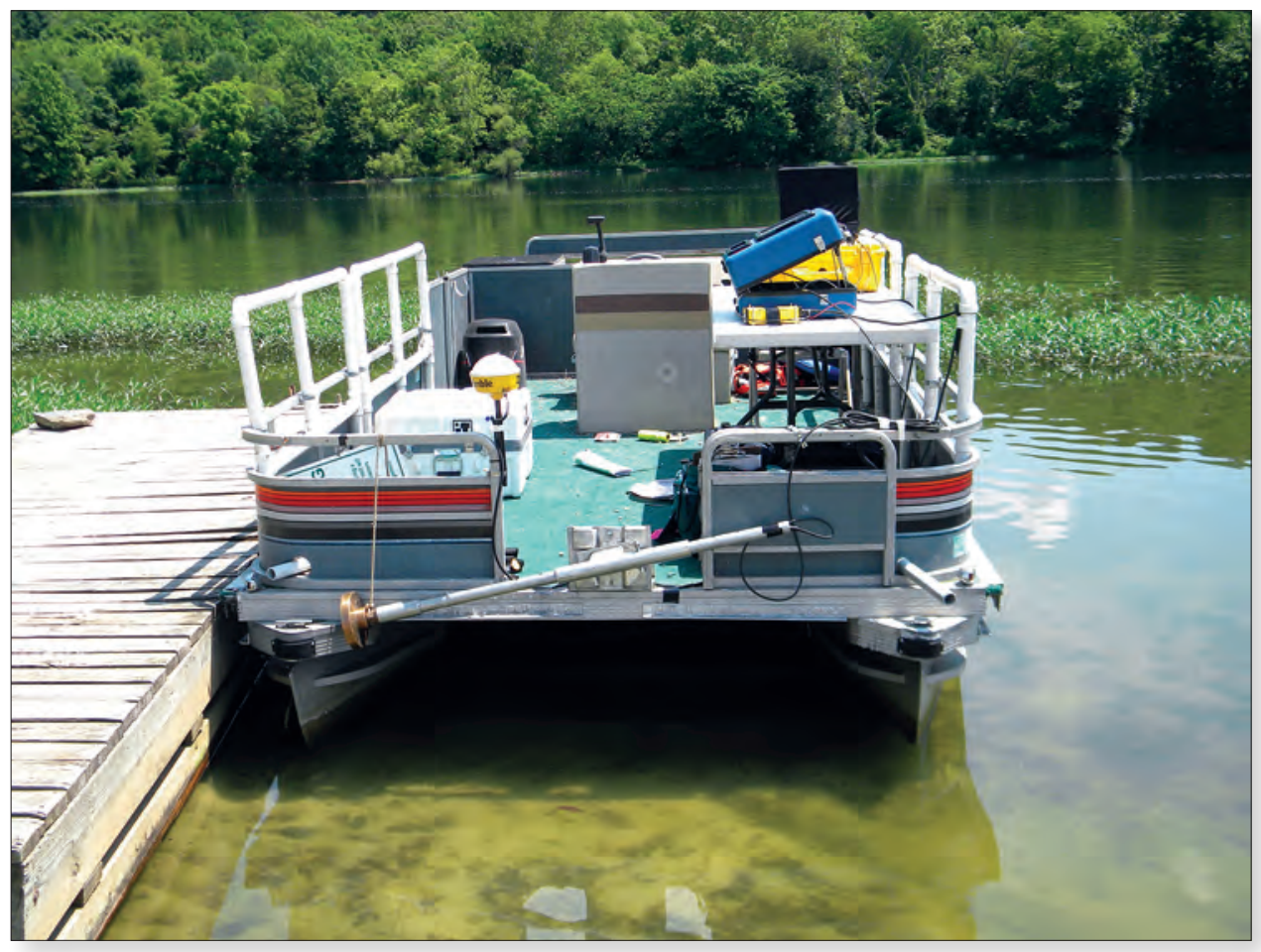

Figure 4. Work boat and data-collection and processing equipment. [Photograph by William Banks, U.S. Geological Survey, 2009.] 
through a graphical user interface to assist in navigation of the boat. This allowed the boat operator and scientists to view the current location of the boat in relation to the predetermined survey lines. Data were collected at a rate of 5 data points per second. The average boat speed was approximately 3 knots, with maximum speeds as high as 5 knots. At these speeds and data acquisition rates, a data point was generated approximately every $1 \mathrm{ft}$ of linear distance traveled on each transect, producing a dataset of 64,075 data points across the study area. No data were collected in areas of the lake where water depth was not sufficient for boat operations

(fig. 5). Additional target data points were collected at locations where navigation to projected plan lines was not possible due to safety concerns (dam spillway) or limited maneuverability (cove on the north-central part of the lake in figure 5). In these areas, target data points were collected to supplement survey data. Target data points involved crew members taking depth measurements by hand and recording the GPS location manually (fig. 5). All points and their associated depths were entered and backed up each day on the USGS computer network.

\section{Data Processing}

In 1971, 16 large-scale topographic maps were produced for the City of Frederick showing parts of the Linganore Creek watershed. The maps represent the part of the basin that was planned to be inundated after construction of Linganore dam and the subsequent filling of Lake Linganore. The maps were constructed using 2-ft contour intervals derived from field surveys in 1971 (Michael Marschner, Director of Public Utilities and Solid Waste, Frederick County, Maryland, written commun., June 10, 2009). For the current study, the City of Frederick provided digital copies of the maps at a 1:600 scale. These maps provided a reference surface that was used to calculate sediment accumulation in the study area.

Scaled images of the maps were imported into a GIS and were geo-referenced to properly display the spatial data. This allowed the topographic surface of the valley prior to inundation to be created. To calculate the water volume of the reservoir, a variety of models and interpolations were considered, including an inverse distance-weighted model, a spline model, and kriging techniques. A Triangulated Irregular Network

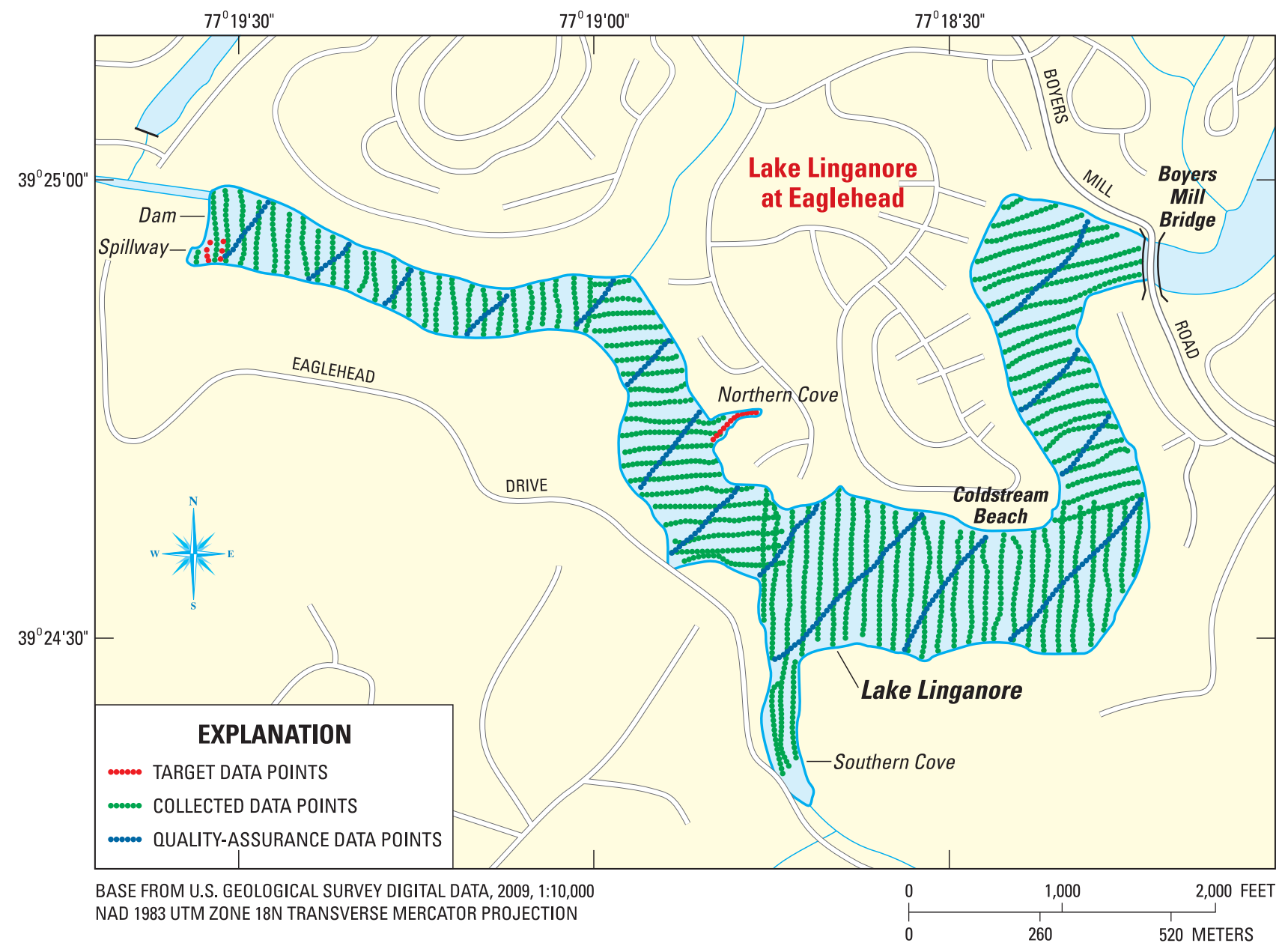

Figure 5. Collected data points, target data points, and quality-assurance data points, Lake Linganore, Maryland, 2009. 
(TIN) model was ultimately chosen on the basis of results achieved by Wilson and Richards (2006), Soler-López (2008), and Kress and others (2005). TIN models have been used to accurately represent reservoir and lake-bottom surfaces for the purpose of determining both water and sediment volume (Wilson and Richards, 2006). The TIN model chosen for this study was created using the three-dimensional analysis tool in ArcGIS (Environmental Systems Research Institute Inc., 2000). Models created using a TIN are built by connecting a set of points to create a network of triangles that form a threedimensional vector-based surface.

Reservoir water-volume calculations are dependent on the accurate representation of a shoreline that is consistent with the elevation of the top of the dam at the spillway. A shoreline was digitized using 1-m (meter) orthophotos collected by the U.S. Department of Agriculture (USDA) National Agriculture Imagery Program (NAIP) in 2005. Additional points were collected during the bathymetric survey to help ensure the digitized shoreline corresponded to a water elevation of 308 $\mathrm{ft}$ (the spillway elevation) and to help define the shoreline in areas where shadows, trees, or other obstructions prevented the use of the NAIP data. Using these additional points and the NAIP orthophotos, a final shoreline was created for use in the current study.

Once data collection was complete, the raw data were examined using HYPACK to identify spurious reflections created by submerged objects, including fish, tree limbs, and other non-bottom reflectors. These artifacts were easily identified by viewing the raw data as a function of linear distance traveled. Non-bottom reflectors were visible as spikes and floating, non-linear data points (fig. 6). These false reflections were removed, and the remaining data were normalized to the spillway elevation of $308 \mathrm{ft}$ and exported as a table containing $\mathrm{x}, \mathrm{y}$, and $\mathrm{z}$ positional values. Normalization on days when lake elevation was less than $308 \mathrm{ft}$ was performed by adding the difference between the full and recorded spillway elevation. On days when the lake elevation exceeded $308 \mathrm{ft}$, the difference was subtracted from the recorded values. Edited data were imported to ArcGIS and a TIN model was created. These data were then constrained to the calculated shoreline. On the few occasions where data points plotted beyond the calculated shoreline, the data points were removed. Cartographically smoothed contours of the lake bottom were then created from the TIN model for map production and visualization purposes. Water and sediment volumes were calculated from the TIN model, rather than the smoothed contours. Another TIN model, created from the digitized 1971 topography, was used in conjunction with the lake-bottom TIN model to calculate sediment volume. A cartographic surface also was created showing areas of sediment deposition and scouring.

\section{Quality Control}

Vertical accuracy was determined by use of guidelines from the National Standard for Spatial Data Accuracy

(NSSDA), which require an independent quality-assurance and

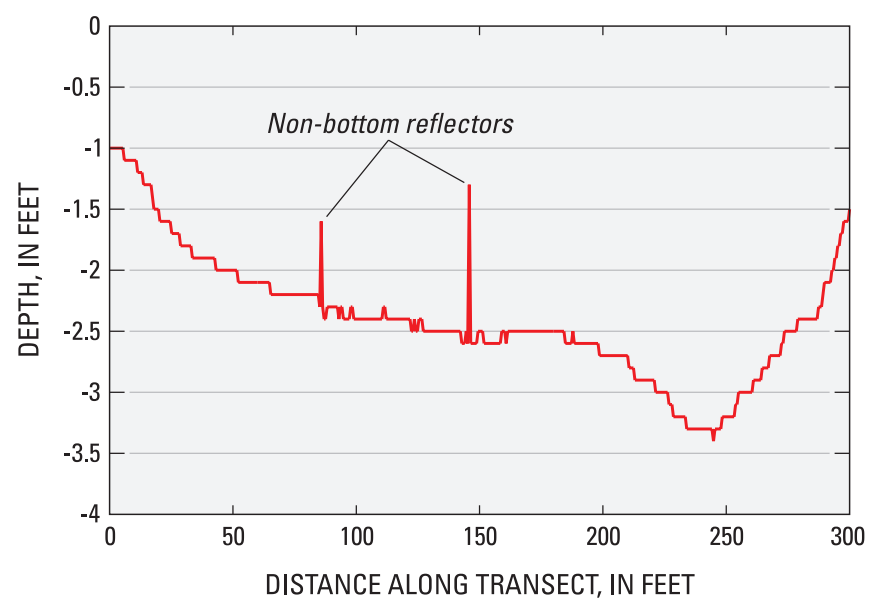

Figure 6. Raw data and non-bottom reflectors, Lake Linganore, Maryland, 2009.

quality-control dataset (Federal Geographic Data Committee, 1998). Quality-assurance data points were compared to coincident data points from the environmental survey. Points were considered to be coincidental if they were less than $0.5 \mathrm{ft}$ apart in horizontal distance. To determine the precision in this measurement, the square root of the mean of the squared residuals (or RMSE) was calculated using equation (1) below.

$$
R M S E_{z}=\sqrt{\left[\sum\left(Z_{\text {data }_{i}}-Z_{\text {check }_{i}}\right)^{2} / n\right]}
$$

where

$$
\begin{aligned}
& R M S E_{z} \quad=\text { root mean square error of the } z \text {, or vertical } \\
& \text { component; } \\
& Z_{\text {data }}=\text { the coordinate of the } i^{\text {th }} \text { check point in the } \\
& \text { environmental dataset; } \\
& Z_{\text {check }}=\text { the coordinate of the } i^{\text {th }} \text { check point in the } \\
& \text { quality-assurance dataset; and } \\
& n \quad=\text { the number of coincidental points. }
\end{aligned}
$$

When compared to the environmental dataset, there were 90 points measuring depth at coincidental locations. Absolute differences between the two datasets ranged from $0.0 \mathrm{ft}$ to $1.24 \mathrm{ft}$. Differences tended to be negatively biased as depth increased. The median depth of the environmental data at coincidental quality-control locations was $13.71 \mathrm{ft}$. Using equation (1) above, a RMSE $\mathrm{z}_{\mathrm{z}}$ of $0.11 \mathrm{ft}$ was calculated for depths less than the median, whereas a RMSE $\mathrm{z}_{\mathrm{z}}$ of 0.61 $\mathrm{ft}$ was calculated for depths greater than the median. An overall $\mathrm{RMSE}_{\mathrm{z}}$ of $0.49 \mathrm{ft}$ was calculated for the entire dataset. According to the NSSDA guidelines, a factor of 1.96 is multiplied by the RMSE $\mathrm{z}_{\mathrm{z}}$ to determine vertical accuracy at the 95-percent confidence interval. Thus, depths less than the median have a vertical accuracy of $0.22 \mathrm{ft}$, whereas depths 
greater than the median have a vertical accuracy of $1.20 \mathrm{ft}$ at the 95-percent confidence interval. Overall, this procedure indicates that vertical data collected for this study have an accuracy of plus or minus $0.95 \mathrm{ft}$. The vertical accuracies of the bathymetric surface model and the bathymetric contour map were $1.53 \mathrm{ft}$ and $3.62 \mathrm{ft}$, respectively, at the 95 -percent confidence interval using the NSSDA guidelines.

A latency test can be used to determine the delay between the time when positioning data are received and the time attributed to the signal leaving the echo sounder. This delay is determined by moving the test vehicle along reciprocal survey lines over a steep bank - in this case, the upstream face of the dam. Latency usually results in a negative, alongtrack displacement of the depth value. Surveys performed at slow speeds generally have small displacement values (U.S. Army Corps of Engineers, 2002). Latency in the current study, according to the parameters stated above, was 0.45 seconds. At an average survey speed of 3.0 knots (5.06 feet per second), the resulting offset was $2.3 \mathrm{ft}$. This offset was compared to the 3.28 -ft horizontal position accuracy given by the manufacturer (Trimble Navigation Limited, 1999). This indicates that horizontal error caused by the time delay between transmission and reception of depth data would be less than the horizontal accuracy of the GPS. Given the slow velocity of the boat, the relatively shallow depths encountered, and the accuracy of the positional data, no latency correction was applied.

\section{Water Volume}

The water-storage volume of Lake Linganore was calculated to be 1,860 acre-ft at full pool elevation (table 1). Full pool, the elevation where the water level is equal to that of the dam spillway, is $308 \mathrm{ft}$ for Lake Linganore. Median water depth of the reservoir is $14.36 \mathrm{ft}$, with a maximum depth near the spillway of nearly $40 \mathrm{ft}$. Although obscured, the remnant of pre-inundation Linganore Creek bed can be seen in the data as a linear feature of deeper water extending from the southern side of Boyers Mill Road bridge, crossing the lake and following the western shore south to Coldstream Beach, continuing south across the lake to the southern shore where it runs west to the mouth of the Southern Cove, and from there following the center line of the lake until it reaches the north end of the dam (fig. 7).

Water volume in the reservoir has decreased by at least 350 acre-ft (about 16 percent) in the 37 years since the dam was constructed. This difference was calculated by subtracting the potential storage volume in the reservoir as measured from the digitized 1972 topography (2,210 acre-ft between the dam and Boyers Mill Road bridge) and the 2009 survey volume of 1,860 acre-ft covering the same area. This difference corresponds to an average loss of 9.40 acre-ft per year. The areato-capacity relation from the TIN model bathymetric data for Lake Linganore downstream from Boyers Mill Road bridge is shown in table 1 . The corresponding elevation-capacity
Table 1. Area/capacity from Triangulated Irregular Network model of bathymetric data collected from Lake Linganore, Frederick County, Maryland, 2009.

\begin{tabular}{ccc}
\hline $\begin{array}{c}\text { Elevation' } \\
\text { (feet) }\end{array}$ & $\begin{array}{c}\text { Area } \\
\text { (acres) }\end{array}$ & $\begin{array}{c}\text { Capacity } \\
\text { (acre-feet) }\end{array}$ \\
\hline 272 & 0 & 0.1 \\
\hline 276 & 4 & 8.9 \\
\hline 280 & 7 & 30.5 \\
\hline 284 & 13 & 68.7 \\
\hline 288 & 24 & 138 \\
\hline 292 & 47 & 276 \\
\hline 296 & 76 & 525 \\
\hline 300 & 101 & 877 \\
\hline 304 & 126 & 1,340 \\
\hline 308 & 137 & 1,860 \\
\hline
\end{tabular}

${ }^{1}$ Elevation is referenced to the North American Vertical Datum of 1988.

curve for the lake is shown in figure 8 . There is a decrease in capacity of 520 acre-ft (28 percent) for the first 4-ft drop in water elevation. As water elevation decreases further, capacity loss averages about 19 percent for every $4 \mathrm{ft}$ until $292 \mathrm{ft}$, where the capacity loss over the last $22 \mathrm{ft}$ averages 3 percent for every $4 \mathrm{ft}$.

In order to analyze changes in water volume, the lake was divided into three approximately equal-area sections. Section 1 extends from Boyers Mill Road bridge to a point 3,100 $\mathrm{ft}$ downstream, just east of the beach on Coldstream Drive. Section 2 lies between sections 1 and 3. Section 3 extends from the dam to a point $4,500 \mathrm{ft}$ east of the dam (fig. 9). Water volume in section 1 is 410 acre- $\mathrm{ft}-\mathrm{a}$ decrease of 28 percent from the original estimated volume of 570 acre$\mathrm{ft}$ as calculated from the 1972 topography. Water volume in section 2 decreased 13 percent, from 690 acre-ft to 600 acre-ft. The water volume in section 3 was originally 950 acre-ft and was calculated to be 850 acre-ft in 2009, a decrease of 11 percent (table 2). The ratio of current water-storage volume compared to the original water-storage volume for each section has changed. In 1972, section 1 represented 26 percent of the total storage, and in 2009, it represented 22 percent of the total storage. Section 2 was approximately unchanged at 32 percent of total capacity, and the storage as a percent of total reservoir capacity of section 3 (the section nearest the dam) increased slightly from 43 percent in 1972 to 46 percent in 2009. This indicates that Lake Linganore is filling in a downstream direction, with infilling occurring more rapidly in the upstream third of the reservoir. 


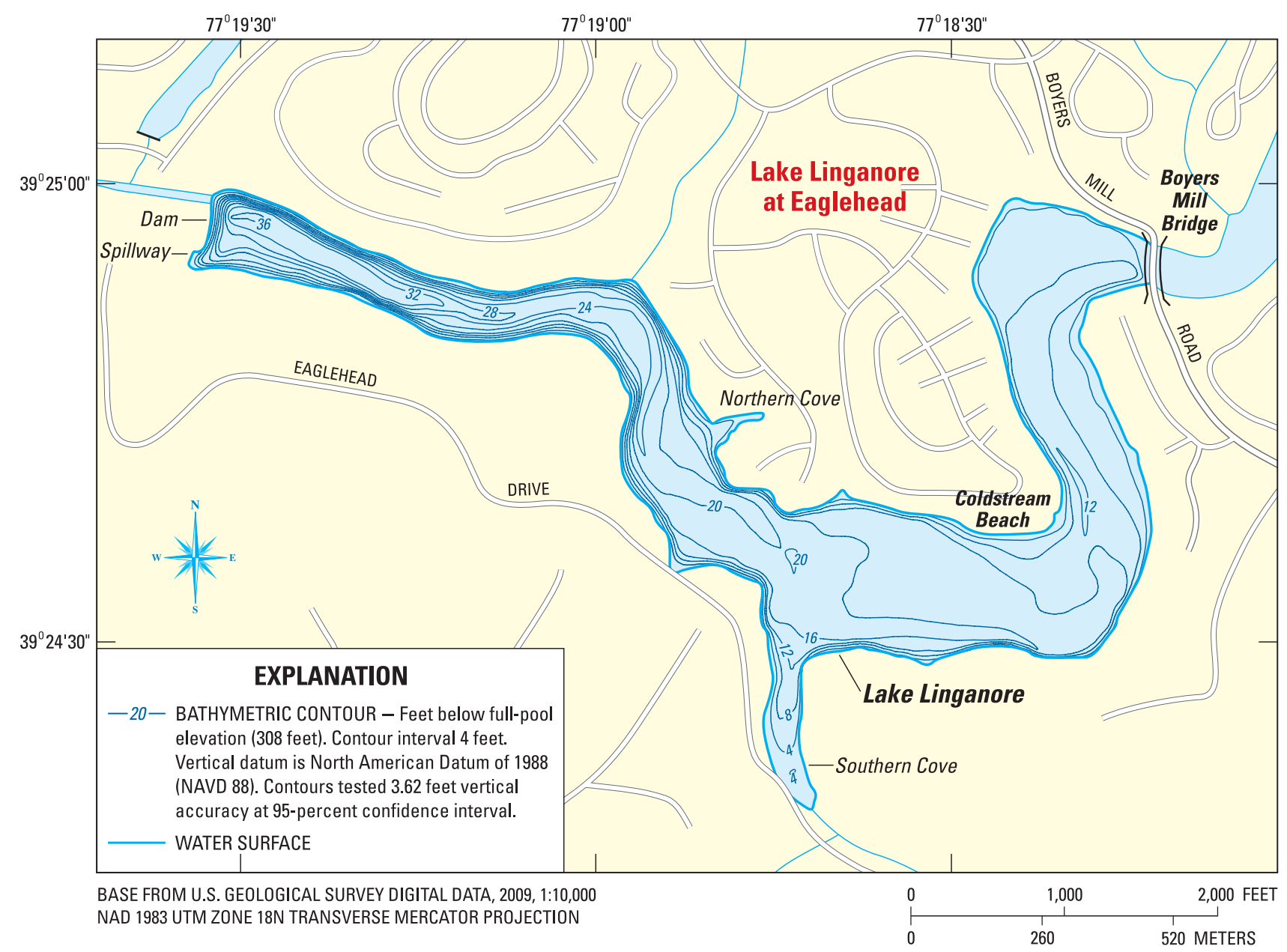

Figure 7. Bathymetric contours of Lake Linganore, Maryland, 2009.

\section{Sediment Accumulation}

The total calculated volume of sediment deposited in the lake below Boyers Mill Road bridge since 1972 is 313 acre-ft. There is a 37 acre-ft difference between estimated water-volume loss and sediment-volume accumulation based on the calculations in the preceding section. This difference may be attributed to the exclusion of the water volumes in the vicinity of the dam and in the Southern Cove in the sediment calculations (fig. 10). There were no data for either of these features in the 1972 topography. The sediment accumulation corresponds to an average rate of 8.46 acre- $\mathrm{ft}$ per year over the 37 years since Linganore Creek was impounded. Median sediment depth is $2.65 \mathrm{ft}$, with maximum depths reaching nearly $20 \mathrm{ft}$ (fig. 10) in selected locations along parts of the remnant Linganore Creek bed. Section 1, the section farthest upstream near the bridge on Boyers Mill Road where Linganore Creek opens up to the lake, has the largest amount of deposited sediment, with 142 acre-ft, or 45 percent of the total sediment accumulation in the lake since 1972. The next downstream section, section 2, contains 87 acre-ft of sediment and accounts for 28 percent of the total volume of sediment accumulation. The volume of sediment in section 3, the section closest to the dam, is nearly the same as the volume of sediment in section 2 at 84 acre-ft, or 27 percent of the total sediment accumulation in the lake.

There are also areas of scour (areas where the elevation of the 2009 lake bottom elevation was less than the 1972 surface elevation). These areas represent 56.7 acre-ft of water storage gained. Scour has occurred primarily along the lake margin, with areas up to $12 \mathrm{ft}$ near Coldstream Beach (fig. 10). This may be a result of beach construction or maintenance activities. Outside the area near Coldstream Beach, most scour occurs along the shoreline in section 3 (fig. 10), often associated with private property or boat docks. These areas of scour near the shoreline could also be the result of using a bathymetric dataset and a pre-dam topographic surface of different accuracies and collection methods.

To show how sediment accretion has occurred in Lake Linganore, a three-dimensional cross section was developed from the TIN model (fig. 11). Sediment accretion in Lake Linganore has occurred preferentially in the bed of the inundated Linganore Creek. Although not shown in the cross 


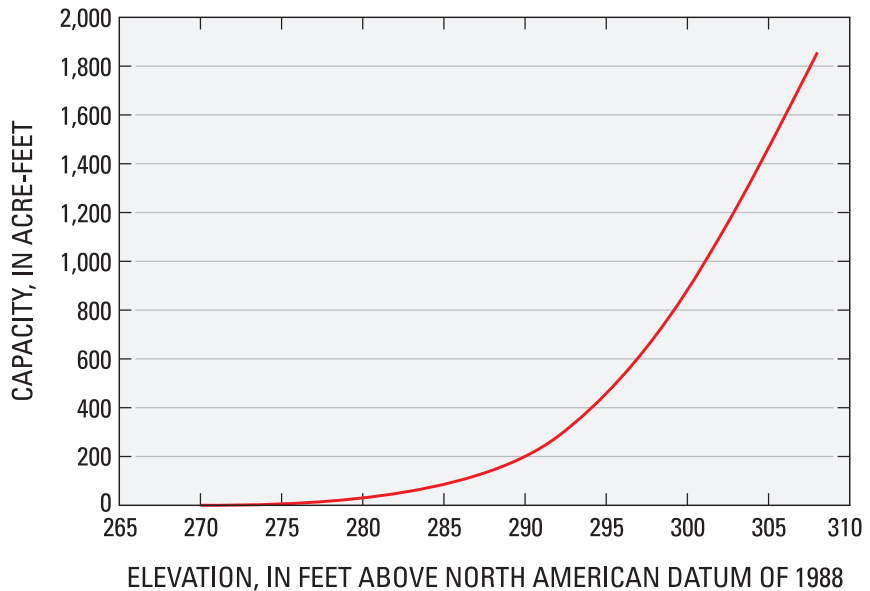

Figure 8. Elevation-capacity curve for Lake Linganore, Maryland, 2009. section, this effect is more pronounced upstream in wider areas of the lake where the original trace of the creek is most evident (fig. 10). To quantify this effect, a buffer of $20 \mathrm{ft}$ was applied to either side of the thalweg of Linganore Creek throughout the study area. Once filled, this channel represents a volume of 25 acre-ft of sediment or 8 percent of the total accumulated sediment in the lake since 1972. The mean sediment depth along the 10,800-ft creek channel is $6.68 \mathrm{ft}$. Removal of this sediment would increase water-storage volume by 1.1 percent of the original 1972 reservoir storage capacity.

Other reservoirs in the Maryland Piedmont Physiographic Province have had different rates of sediment accumulation. Loch Raven Reservoir in Baltimore County, Maryland has a drainage area of $219.4 \mathrm{mi}^{2}$, nearly 3 times larger than the drainage area of Lake Linganore. Most of the watershed is lightly wooded or has been cleared of vegetation for agricultural activities, and to support housing for the suburbs of Baltimore City. Loch Raven had an average sediment accumulation rate of $0.88 \mathrm{yd}^{3} \mathrm{yr}^{-1}$ acre ${ }^{-1}$ (cubic yards per year per acre) (Banks and LaMotte, 1999). By comparison, Lake Linganore had a sediment accumulation rate of $0.26 \mathrm{yd}^{3} \mathrm{yr}^{-1}$ acre $^{-1}$. However, a potentially large amount of sediment in

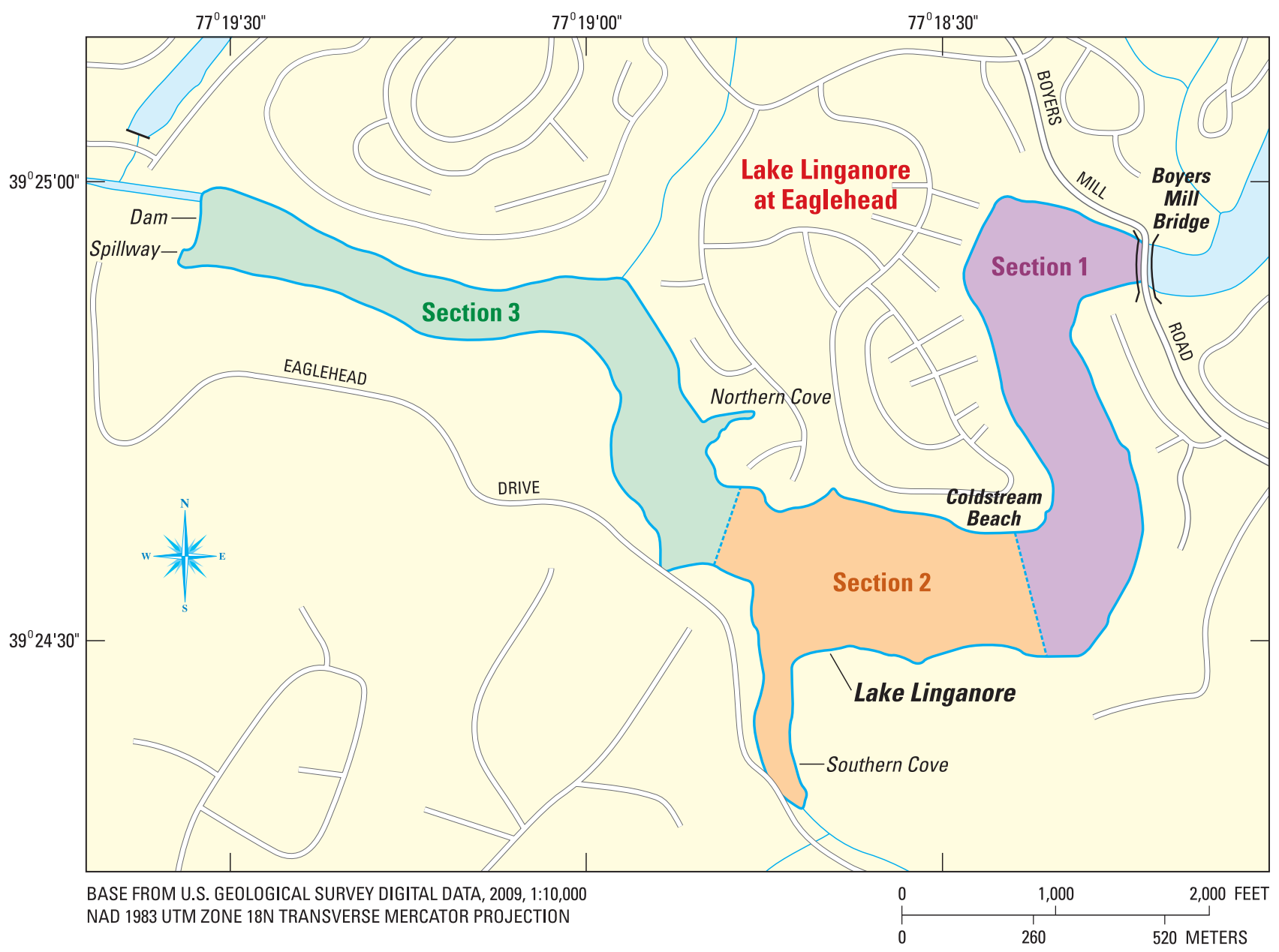

Figure 9. Study sections of Lake Linganore, Maryland, 2009. 
Table 2. Water-storage capacity, water volume, and sediment accumulation in Lake Linganore, Frederick County, Maryland, 2009.

\begin{tabular}{ccccccccc}
\hline $\begin{array}{c}\text { Section } \\
\text { (locations } \\
\text { shown in } \\
\text { figure 9) }\end{array}$ & $\begin{array}{c}\text { Surface area } \\
\text { (acres) }\end{array}$ & $\begin{array}{c}\text { Water } \\
\text { volume at } \\
\text { full-pool } \\
\text { elevation } \\
\text { (acre-feet) }\end{array}$ & $\begin{array}{c}\text { Storage } \\
\text { volume as a } \\
\text { percentage } \\
\text { of total } \\
\text { volume }\end{array}$ & $\begin{array}{c}\text { Potential } \\
\text { 1972 water } \\
\text { volume } \\
\text { (acre-feet) }\end{array}$ & $\begin{array}{c}\text { Potential } \\
\text { 1972 storage } \\
\text { volume as a } \\
\text { percentage } \\
\text { of total } \\
\text { volume }\end{array}$ & $\begin{array}{c}\text { Percent } \\
\text { change of } \\
\text { storage } \\
\text { capacity } \\
\text { between } \\
\text { 1972 and 2009 }\end{array}$ & $\begin{array}{c}\text { Sediment } \\
\text { volume } \\
\text { (acre-feet) }\end{array}$ & $\begin{array}{c}\text { Percent of } \\
\text { total } \\
\text { sediment } \\
\text { accumulation }\end{array}$ \\
\hline $\mathbf{1}$ & 45.6 & 410 & 22 & 570 & 26 & 28 & 142 \\
\hline $\mathbf{3}$ & 45.7 & 600 & 32 & 690 & 31 & 43 & 87 \\
\hline Total & 45.7 & 850 & 46 & 950 & 43 & 11 & 28 \\
\hline
\end{tabular}

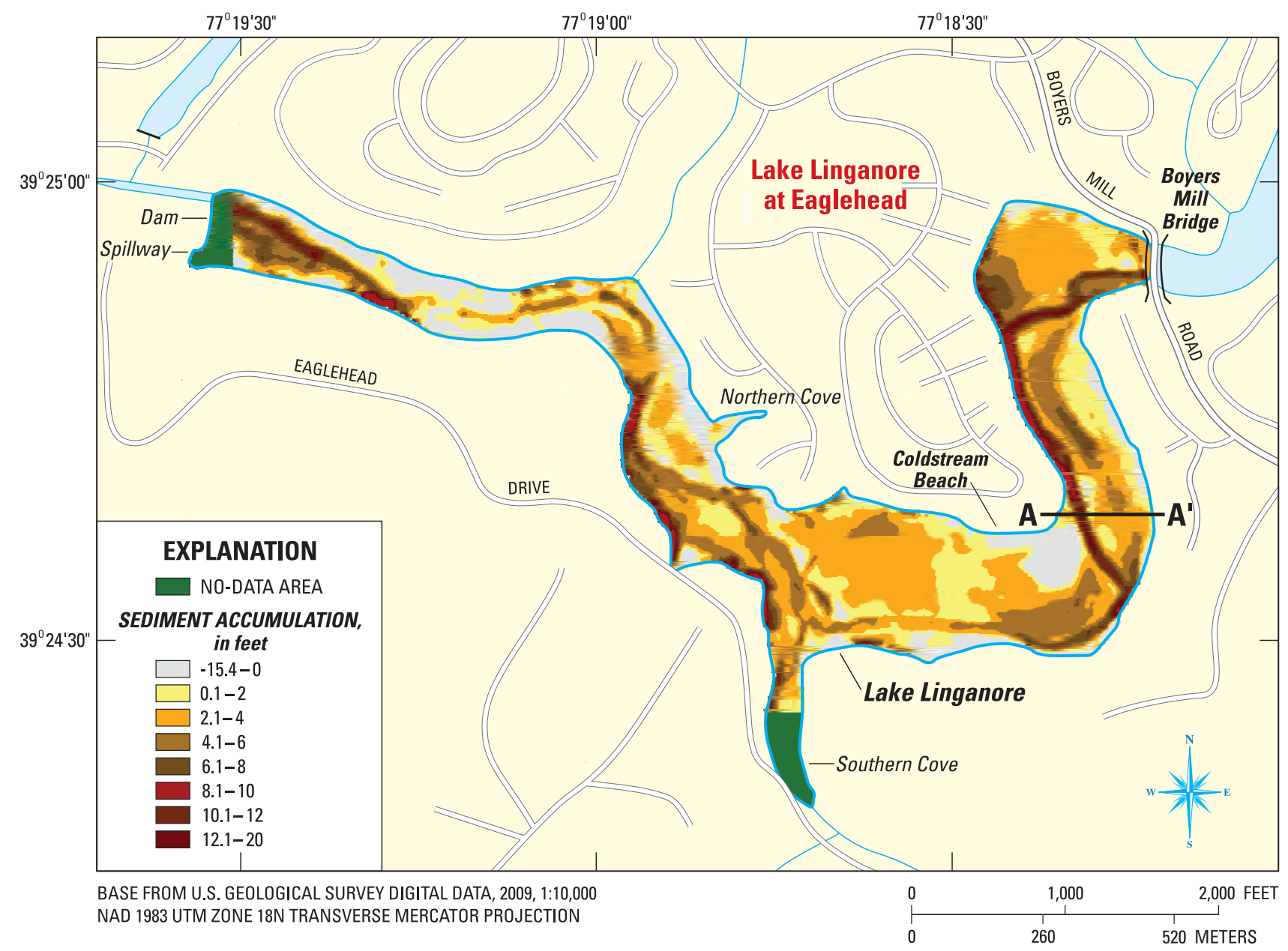

Figure 10. Sediment accretion and scour in Lake Linganore, Maryland, 2009. (Cross section A-A' shown in figure 11.) 


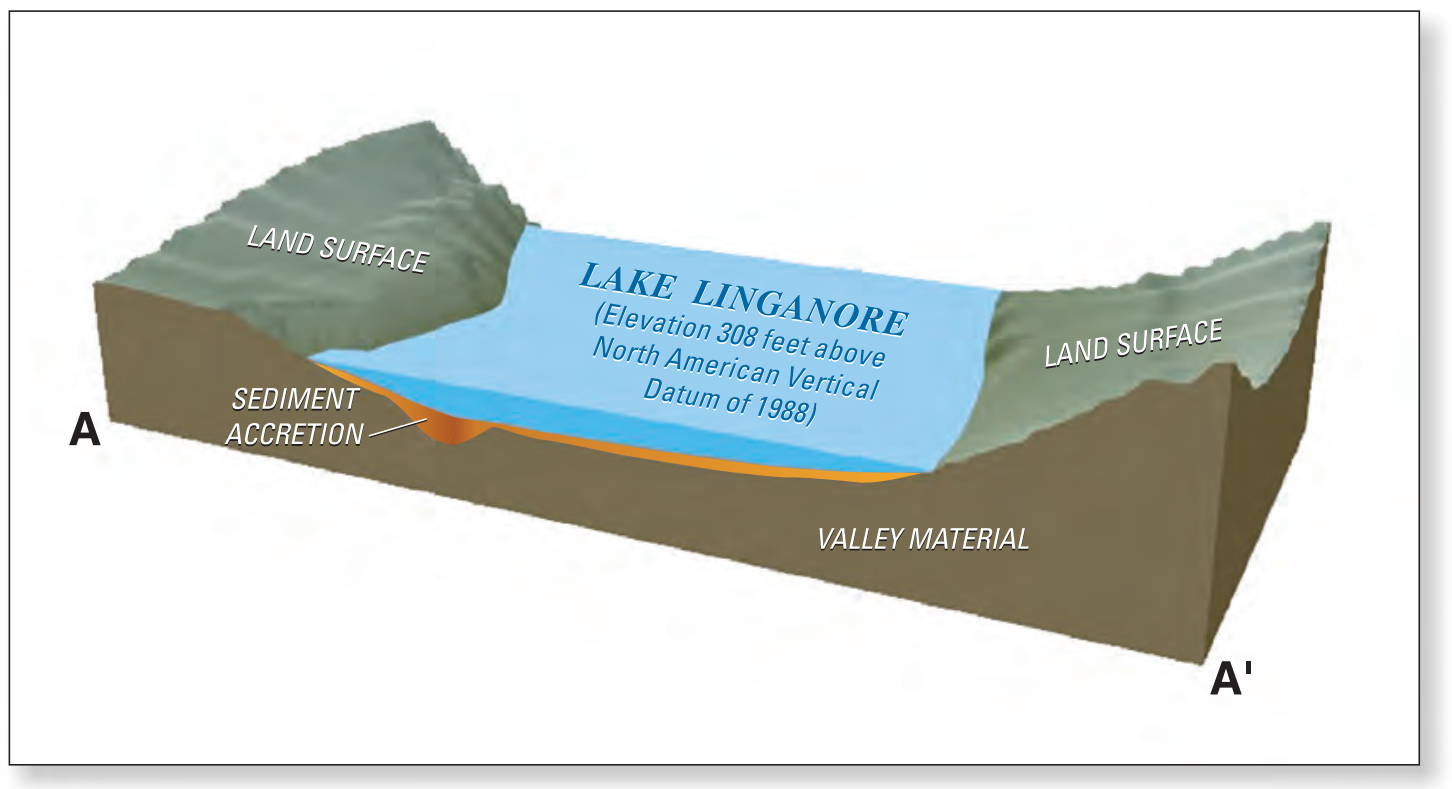

Figure 11. Generalized cross section of Lake Linganore from section 1, Lake Linganore, Maryland, 2009.

this study was not accounted for upstream of the Boyers Mill Road bridge. This area was not included due to the shallow depths encountered and the inability to access this area with the equipment used. This area could be examined by use of other methods to estimate the amount of sediment residing upstream of the Boyers Mill Road bridge. As is the case with Loch Raven Reservoir, it is possible that sediment will be transported further down into the reservoir in the future and the rate of sedimentation will increase (Ortt and others, 2000). Prettyboy Reservoir, in Baltimore County, Maryland, has a drainage area of $80 \mathrm{mi}^{2}$ and an average sediment accumulation rate of $2.23 \mathrm{yd}^{3} \mathrm{yr}^{-1} \mathrm{acre}^{-1}$ (Ortt and others, 2000). Piney Run Reservoir, located in Carroll County, Maryland, was constructed in 1974. Land use in the watershed is similar to land use surrounding Linganore Creek - predominantly agriculture, with about 20 percent developed land (Maryland Department of the Environment, 2002). However, Piney Run Reservoir has a drainage area that represents only 12 percent of Lake Linganore's 81.1- $\mathrm{mi}^{2}$ watershed. A sedimentation analysis of Piney Run Reservoir conducted in 1989 found little evidence of deposition with a calculated volume loss of 0.4 percent. The analysis concluded that the low sediment deposition may have resulted from the widespread use of no-till farming in the small watershed (Maryland Department of the Environment, 1989).

Although Piney Run Reservoir and Lake Linganore have similar land uses within their respective watersheds, the much smaller Piney Run watershed may contribute to lower sedimentation rates. Land-use distribution within the watershed may also play a role in reservoir sedimentation. Conversely, Loch Raven Reservoir's sedimentation rate (between those of Lake Linganore and Piney Run) may be a result of a larger and more developed watershed.

\section{Summary}

A bathymetric survey and sediment analysis was performed by the U.S. Geological Survey, in cooperation with the City of Frederick and Frederick County, Maryland in Lake Linganore, Frederick County, Maryland. The survey was conducted in order to calculate water volume and sediment accumulation in the lake to better understand sediment and phosphorus loadings and to better manage water resources. Bathymetric data points were collected to determine the elevation of the lake bottom. To determine the amount of sediment accumulated since the construction of the dam in 1972, contour lines of the study area prior to dam construction were digitized and a surface was created using Geographic Information System software. Current water and sediment volumes were calculated using Triangulated Irregular Network models and by comparing the current lake bottom to the pre-inundation topography of the study area. The total water volume of the reservoir as calculated in 2009 was 1,860 acrefeet. Accumulated sediment volume in the reservoir since the dam was constructed in 1972 was 313 acre-feet. Due to sediment deposition in the lake, water volume has decreased approximately 16 percent. An analysis of the distribution of the sediment indicated that the largest volume of sediment was located in the most upstream third of Lake Linganore, whereas the third of the lake closest to the dam contained the largest amount of water. Lake Linganore was found to have one of the lowest sedimentation rates in comparison to three other Maryland Piedmont reservoirs, at 0.26 cubic yards per year per acre of drainage area. 


\section{Acknowledgments}

The authors wish to thank Andrew LaMotte and Michael Wieczorek (USGS) for their GIS and cartography assistance. William Davies (USGS) also provided excellent support and guidance with electrical equipment and set-up. The authors also wish to thank Ray Baker, who was the boat operator during data collection.

\section{References Cited}

Banks, W.S.L., and LaMotte, A.E., 1999, Sediment accumulation and water volume in Loch Raven Reservoir, Baltimore County, Maryland: U.S. Geological Survey Water-Resources Investigations Report 99-4240.

DiLisio, J.E., 1983, Maryland: A geography: Boulder, Colorado, Westview Press, Inc., 233 p.

Environmental Systems Research Institute, Inc., 2000, Using ArcGIS 3D Analyst: Redlands, California, ESRI Press, 261 p.

Federal Geographic Data Committee, 1998, Geospatial positioning accuracy standards, Part 3: National standard for spatial data accuracy: Subcommittee for base cartographic data, Federal Geographic Data Committee, accessed March 10, 2010 at http://www.fgdc.gov/standards/projects/ FGDC-standards-projects/accuracy/part3/chapter3.

Frederick County, Maryland, 2006, Action plan for the Linganore source water protection plan, accessed March 10, 2010 at http://www.frederickcountymd.gov/documents/Planning/ Environmental\%20 Planning/LingActionPlan.pdf.

Gellis, A.C., Hupp, C.R., Pavich, M.J., Landwehr, J.M., Banks, W.S.L., Hubbard, B.E., Langland, M.J., Ritchie, J.C., and Reuter, J.M., 2009, Sources, transport, and storage of sediment in the Chesapeake Bay Watershed: U.S. Geological Survey Scientific Investigations Report 2008-5186, 95 p., available online at http://pubs.usgs.gov/sir/2008/5186/.

HYPACK, 2008, User's Manual 2/08, Hypack Inc., Middletown, Connecticut, accessed March 10, 2010 at http://www.hypack. $\mathrm{com} /$.

Kress, W.H., Sebree, S.K., Littin, G.R., Drain, M.A., and Kling, M.E., 2005, Comparison of preconstruction and 2003 bathymetric and topographic surveys of Lake McConaughy, Nebraska: U.S. Geological Survey Scientific Investigations Report 2005-5040, 19 p., available online at http://pubs.usgs. gov/sir/2005/5040/.
Maryland Department of the Environment, 1989, Water quality analysis of sedimentation for Piney Run Reservoir in Carroll County, Maryland: Maryland Department of the Environment, Final Report Submitted to U.S. Environmental Protection Agency, Region III, accessed March 10, 2010 at http://www. mde.state.md.us/assets/document/Piney\%20Run\%20sediment_ final.pdf.

Maryland Department of the Environment, 2002, Total Maximum Daily Loads of Phosphorus and Sediments for Lake Linganore, Frederick County, MD: Maryland Department of the Environment, Final Report Submitted to U.S. Environmental Protection Agency, Region III, accessed March 10, 2010 at http://www.mde.state.md.us/assets/document/Linganore_eutro_ final.pdf.

National Oceanic and Atmospheric Administration, 2006, Maryland MARFC average precipitation (inches), National Weather Service Mid-Atlantic River Forecast Center, accessed March 10, 2010 at http://www.erh.noaa.gov/marfc/ Climatology/mdppn.htm.

Ortt, R.A., Kerhin, R.T., Wells, Darlene, and Cornwell, Jeff, 2000, Bathymetric survey and sedimentation analysis of Loch Raven and Prettyboy Reservoirs: Maryland Geological Survey, Coastal and Estuarine Geology Report No. 99-4, 89 p., available online at http://www.mgs.md.gov/coastal/pubFR99_4.html.

Soler-López, L.R., 2008, Sedimentation survey of Lago La Plata, Puerto Rico, July 2006: U.S. Geological Survey Scientific Investigations Map 2008-3021, available online at http://pubs. usgs.gov/sim/3021/.

Trimble Navigation Limited, 1999, AgGPS 123/132 Operation manual, revision B: Overland Park, Kansas, Trimble Precision Agricultural Systems, 218 p.

U.S. Army Corps of Engineers, 2002, Engineering and design-Hydrographic surveying manual No. 1110-2-1003: Washington, D.C., 510 p.

U.S. Census Bureau, 2009, 1990 and 2000 population, American Fact Finder, accessed March 10, 2010 at http://www.factfinder. census.gov.

Whitman, Requardt \& Associates, 2002, Lake Linganore, Frederick County, Maryland siltation \& capacity report: Baltimore, Maryland, [variously paged].

Wilson, G.L., and Richards, J.M., 2006, Procedural documentation and accuracy assessment of bathymetric maps and area/ capacity tables for small reservoirs: U.S. Geological Survey Scientific Investigations Report 2006-5208, 24 p. plus oversize figs., available online at http://pubs.usgs.gov/sir/2006/5208/.

Zeigler, E.J., 1980, National Dam Inspection Program, Lake Linganore (NDI-ID Number MD-21) Potomac River Basin, Linganore Creek, Frederick County, Maryland, Phase I Inspection Report: Baltimore, Maryland, Rummel, Klepper \& Kahl, [variously paged]. 
Prepared by USGS West Trenton Publishing Service Center. Edited by Valerie M. Gaine.

Graphics and layout by Timothy W. Auer.

For additional information, contact:

Director, MD-DE-DC Water Science Center

U.S. Geological Survey

5522 Research Park Drive

Baltimore, MD 21228

or visit our Web site at: http://md.water.usgs.gov 
